\title{
IMMUNOLOGICAL MARKERS OF LONG-TERM EFFECTS OF TREATMENT IN PATIENTS WITH MILD COGNITIVE IMPAIRMENT
}

\author{
S.A. Krynskiy ${ }^{1}$, I.K. Malashenkova ${ }^{1,2}$, N.A. Hailov ${ }^{1}$, D.P. Ogurtsov ${ }^{1,2}$, E.I. Chekulaeva ${ }^{1}$, \\ E.V. Ponomareva ${ }^{3}$, S.I. Gavrilova ${ }^{3}$, N.A. Didkovsky ${ }^{2}$ \\ ${ }^{1}$ NRC "Kurchatov Institute”, Russia; \\ ${ }^{2}$ FSBI FCRC of Physical-Chemical Medicine FMBA of Russia, Moscow, Russia; \\ ${ }^{3}$ FSBSI "Mental Health Research Center", Moscow, Russia

\section{ИММУНОЛОГИЧЕСКИЕ МАРКЕРЫ ДОЛГОСРОЧНЫХ ЭФФЕКТОВ ТЕРАПИИ У ПАЦИЕНТОВ С СИНДРОМОМ МЯГКОГО КОГНИТИВНОГО СНИЖЕНИЯ}

\author{
С.А. Крынский ${ }^{1}$ И.К. Малашенкова ${ }^{1,2}$, Н.А. Хайлов ${ }^{1}$, Д.П. Огурцов ${ }^{1,2}$, Е.И. Чекулаева ${ }^{1}$, \\ Е.В. Пономарева ${ }^{3}$, С.И. Гаврилова ${ }^{3}$, Н.А. Дидковский ${ }^{2}$ \\ ${ }^{1}$ НИЦ «Курчатовский институт», Москва; \\ 2 ФНКЦ физико-химической медицины, Москва; \\ ${ }^{3}$ ФГБНУ «Научный центр психического здоровья», Москва
}

srgkr002@gmail.com

The goal of this research was to study the clinical efficacy of course-based neurotrophic therapy in mild cognitive impairment (MCI) and the effect of therapy on immune parameters in patients, and to assess the prognostic value of the dynamics of immune parameters during the year after treatment. 20 patients with MCI receiving intravenous Cerebrolysin (20 infusions of $30 \mathrm{ml}$ with increasing dose during the first four days) were examined. Neuropsychological and immunological examination was carried out immediately before the study, after 3 months., 6 months and after 1 year after the end of treatment. It was found that after therapy, patients had a long-term decrease in the severity of systemic inflammatory response, and that marked signs of systemic inflammation at the beginning of follow-up combined with a persistent decrease in the level of immunoglobulin $\mathrm{G}$ in dynamics were prognostic markers of MCI progression. In conclusion, it wass shown that neurotrophic therapy has a good clinical effect and has a favorable immunomodulatory effect in aMCI, and the relationship between the dynamics of humoral immunity and systemic inflammation and the risk of progression of cognitive impairment in patients within 1 year after therapy was established.

Keywords: Alzheimer's disease; immunoglobulin G; mild cognitive impairment; systemic inflammation; IL-8.

Изучали влияние нейротрофической терапии на показатели иммунной защиты у больных с мягким когнитивным снижением (MCI), прогностическое значения динамики иммунных показателей в течение года после лечения. Обследованы 20 пациентов с MCI, получавших церебролизин внутривенно. Нейропсихологическое и иммунологическое обследование проводились непосредственно до начала исследования, через 3 мес., 6 мес. и спустя 1 год после окончания лечения. Выявлено, что выраженные признаки системного воспаления в начале наблюдения и стойкое снижение уровня иммуноглобулина $\mathrm{G}$ в динамике являлись прогностическими маркерами низкого ответа на лечение и прогрессирования МСI.

Ключевые слова: болезнь Альцгеймера; иммуноглобулин G; мягкое когнитивное снижение; системное воспаление; IL-8.

Introduction. Amnestic mild cognitive impairment (aMCI) is currently considered as possible earliest clinical stage of Alzheimer's disease (AD). The risk of dementia in aMCI patients is about $15 \%$ per year (Busse et al., 2006). However, in some patients, cognitive disorders are stable or regress: the rate of cognitive recovery in aMCI reaches, according to various data, from 15 to $30 \%$ (Palmer et al., 2003). Thus, it is important to search for prognostic markers in aMCI. According to contemporary views, long-term latent activation of the mechanisms of innate immune response in the brain contributes to the progression of neurodegeneration in aMCI (Skaper et al., 2018). The rela- tionship between markers of systemic inflammation and neuroinflammation in the early stages of $\mathrm{AD}$, including aMCI, is being actively studied.

The aim of this work was to research the clinical efficacy of neurotrophic therapy with Cerebrolysin in aMCI, the effect of therapy on immune protection in patients, as well as to assess the prognostic value of the dynamics of immune parameters during follow-up.

Materials and methods. 20 patients (16 female, 4 male, age 54-84 years, mean age $72.6 \pm 3.2$ years), corresponding to the diagnosis criteria of aMCI (Petersen, Touchon, 2005), and 17 volunteers of the control group, comparable in 
a

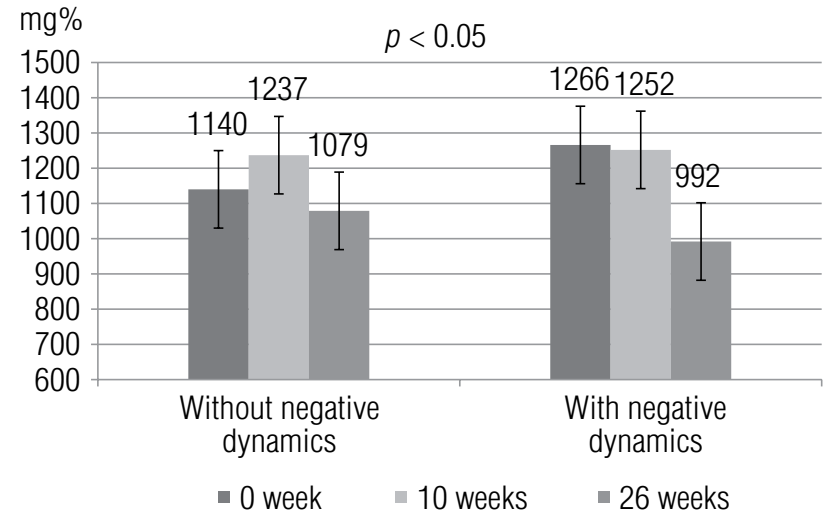

$b$

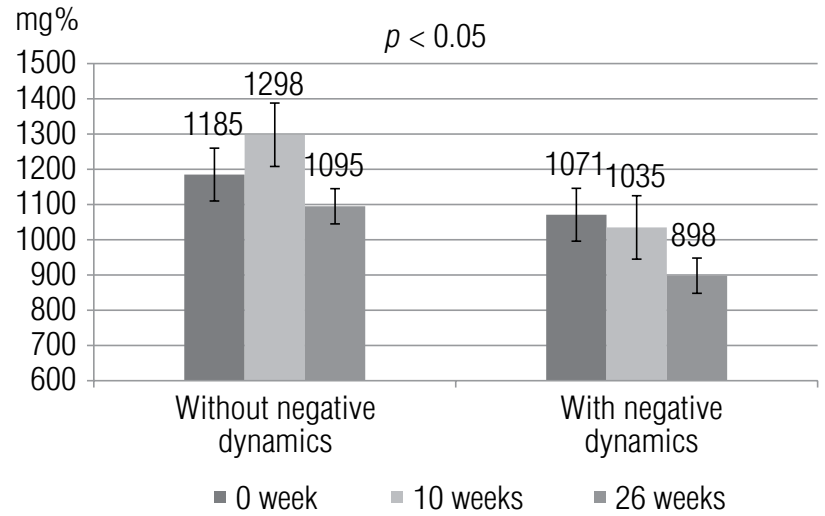

Fig. 1. Changes in the level of total IgG in patients with aMCI during follow-up depending on the dynamics of cognitive function after 6 months $(a)$ and 1 year $(b)$

age and sex with the main group, were included into the study. Patients of the main group underwent 1 course of therapy -20 intravenous infusions of Cerebrolysin of $30 \mathrm{ml}$ with an increase in the dose during the first 4 days $(5,10,20,30 \mathrm{ml})$ in $100 \mathrm{ml}$ of saline. The follow-up was conducted immediately before the study, after 3 months, 6 months, and after 1 year after the end of treatment.

Clinical evaluation of the effectiveness was carried out using neuropsychological scales CGI, MMSE, MoCA-test. Immunological examination included assessment of immunoglobulins $\operatorname{IgA}, \operatorname{IgM}$, $\mathrm{IgG}$, cortisol, C-reactive protein (CRP) (Chemamedic), cytokines IL-2, IL-4, IL-8, TNFa (Vectorbest LLC) by enzyme immunoassay. Microsoft Excel software was used for statistical processing. For comparison of group means student $t$-test was applied. Differences were considered significant at $p<0.05$.

Results and discussion. It was found that 7 patients who developed dementia or expressed negative dynamics of cognitive functions in the dynamics of observation had signs of systemic inflammatory response in all cases (increase in the level of C-reactive protein to values above $5 \mathrm{~g} / \mathrm{l}$ and increase in the level of 2 and more proinflammatory cytokines IL-1 $\beta$, IL- $8, \mathrm{TNFa})$. At the same time, out of 13 patients whose cognitive functions remained stable after 1 year of follow-up, only 7 had signs of systemic inflammation $(p<0.05)$. Thus, the presence of systemic inflammation at the beginning of therapy was prognostically unfavorable in MCI. It was also shown that in patients who had no clinical effect after 3 months the level of IL-8 significantly increased at this point. Of the 10 patients whose IL-8 levels were $<25 \mathrm{pg} / \mathrm{ml}$, 9 had a marked clinical improvement 10 weeks after treatment and 1 had minimal improvement. Of the 10 patients who had IL- $8>25 \mathrm{pg} / \mathrm{ml}$, a marked improvement was noted in 1, 3 had minimal improvement, and 6 had no clinical effect. Thus, a link was found between an increase in the level of IL-8 in dynamics and the lack of optimal effect of therapy. It was also shown that in patients who had systemic inflammation at the start of observation there was a link between changes in the level of total IgG during observation and cognitive functions. Patients with aMCI who had no effect of therapy after 6 months had a decrease in the level of $\operatorname{IgG}$ at this point $(p<0.05)$ compared to the initial level. In addition, the decrease in IgG at 6 months was a marker of further cognitive decline. In the group of 7 patients with cognitive decline after 1 year of follow-up, at 6 months there was also a decrease in the level of IgG compared to the beginning of observation $(p<0.05)$ (Fig. 1).

Conclusion. It was found that detection of signs of systemic inflammation with an increase in IL-8 level above $25 \mathrm{pg} / \mathrm{ml}$ in patients with MCI 3 months after the start of observation was a marker of the absence of favorable short-term dynamics of cognitive functions during therapy. Progression of cognitive impairment in patients with MCI after 1 year of follow-up was associated with the presence of systemic inflammation in combination with a decrease in the level of total $\mathrm{IgG}$ in dynamics after 6 months and 1 year of follow-up.

\section{References}

1. Manly JJ, Tang MX, Schupf N, et al. Frequency and course of mild cognitive impairment in a multiethnic community. Ann Neurol. 2008;63(4):494-506. https://doi.org/10.1002/ana.21326.

2. Palmer K, Fratiglioni L, Winblad B. What is mild cognitive impairment? Variations in definitions and evolution of nondemented persons with cognitive impairment. Acta Neurol Scand. 2003;179:14-20.

3. Skaper SD, Facci L, Zusso M, Giusti P. An Inflammation-Centric View of Neurological Disease: Beyond the Neuron. Front Cell Neurosci. 2018;12:72. eCollection 2018. https://doi.org/10.3389/fncel.2018.00072.

4. Petersen RC, Touchon J. Consensus on mild cognitive impairment. Research and Practice in Alzheimer's Disease, E.A.D.C./A.D.C.S. Joint Meeting (Serdi Publisher, Paris). 2005;10:24-32. 